\title{
KHAWARIJ DAN NEO-KHAWARIJ: Studi Perbandingan Falsafah Politik
}

Oleh :

Aly Masyhar*

\begin{abstract}
Abstrak :
Khawarij adalah salah satu dari tiga sekte awal Islam. Sekte ini mayoritas terdiri dari huffadz dan mempunyai karakter literalis, suka mengkafirkan, dan kekerasan, bahkan tidak segan-segan menghalalkan darah kepada kelompok di luar fahamnya. Antara Khawarij dan Neo-Khawarij mempunyai kesamaan karakter dan konsep politik, meskipun para pakar menyatakan bahwa antara mereka tidak ada kesinambungan secara geneologi. Titik kesamaan yang sangat kentara atau menonjol dari mereka adalah suka mengkafirkan, getol mengumandangkan jihad, melakukan kekerasan dalam menyelesaikan masalah atau kepada kelompok di luar pemahamannya, literer dalam memahami nash, menentang pemerintahan yang sah (pemberontak), menolak semua hal yang tidak terdapat secara lahirinyah dalam nash, dan bahkan menghalalkan darah sesama muslim yang bukan golongannya, dan lain sebagainya. Kelompok yang disinyalir para pakar masuk dalam kategori neokhawarij antara lain Jamaah Islamiyah, al-Qaeda, Wahabi, Salafi, DII/TII, LDII, al-Muhajiroun, dan lain-lain.
\end{abstract}

Kata kunci : Khawarij, Neo-Khawarij, Filsafat Politik.

\section{Pendahuluan}

Akhir-akhir ini, kita sering mendengar peristiwa-peristiwa yang memaksa kita mengelus dada, seperti maraknya pengeboman, merajalelanya teroris, kelompok Islam yang mudah mencerca, mengkafirkan, keras dan sifat-sifat kasar lainnya. Hal itu nampak nyata dan dekat dari kita. Melihat fenomena ini, penulis, dan mungkin mayoritas umat muslim yang cintai kedamaian, bertanya-tanya kenapa Islam yang dulu ramah, santun, menyebarkan kedamaian dan cinta sekarang menjadi beringas, kasar, keras, dan mudah marah? Dulu orang indonesia sangat santun dan ramah sekarang

\footnotetext{
* IAI Tribakti Kediri.
} 
menjadi kebalikannya? Apa yang menyebabkan semua itu terjadi? Dan adakah rentetan atau rujukan kesejarahan terkait hal itu, radikalisme?

Itulah pertanyaan-pertanyaan yang berkelit-kelindan dibenak penulis. Namun, karena keterbatasan waktu dan halaman, dalam kajian singkat ini, penulis akan berusaha mengulas jawaban atas satu pertanyaan dari pertanyaan-pertanyaan itu, yakni jawaban pertanyaan 'Adakah rujukan kesejarahan terkait radikalisme (ideologi-politik) tersebut?'. Karena menurut kajian awal menyatakan ada, yakni sekte Khawarij, maka penulis akan langsung memfokuskan kajian ini pada sekte Khawarij, tepatnya sisi pemikiran politiknya.

Sebelum menuju ke pembahasan inti, penulis akan mengetengah terlebih dahulu derivasi makna Khawarij, sejarah kemunculan, dan baru kemudian pemikiran politiknya dan relasinya dengan kelompok-kelompok yang dikategorikan sebagai neo-khawarij di Indonesia.

\section{Derivasi Makna Khawarij}

Menurut Montgomery Watt, kata Khawarij berasal dari bahasa Arab dan jamak dari kata Khariji dan yang berkata dasar Kharaja yang berarti keluar. Kemudian secara istilah, dari pendapat para pakar yang ada, Watt menklasifikasikannya menjadi empat, yakni: (1) Khawarij adalah mereka yang keluar atau memisahkan diri dari golongan Ali; (2) mereka adalah orang yang keluar dari kalangan orang yang tidak beriman, 'dengan melakukan hijrah kepada Allah dan Rasul-Nya', artinya memutuskan semua ikatan dengan orang-orang yang tidak beriman; (3) mereka adalah orang-orang yang keluar menentang Ali dalam pengertian memberontak terhadap Ali; dan (4) mereka adalah orang-orang yang keluar dan mengambil bagian aktif dalam jihad, berbeda dengan mereka yang, masih tetap, sebagaimana yang dibedakan dalam al-Qur'an surat at-taubah ayat $83-84{ }^{1}$

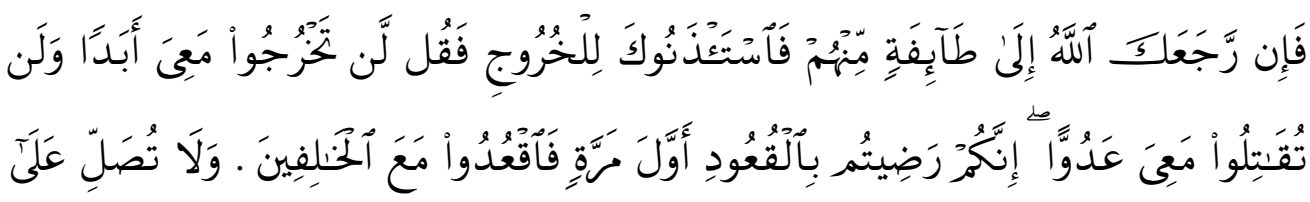

${ }^{1}$ Motgomerry Watt, Studi Islam Klasik: Wacana Kritik Sejarah, terj. Sukoyo, dkk. (Yogyakarta: Tiara Wacana, 1999), 16-20 


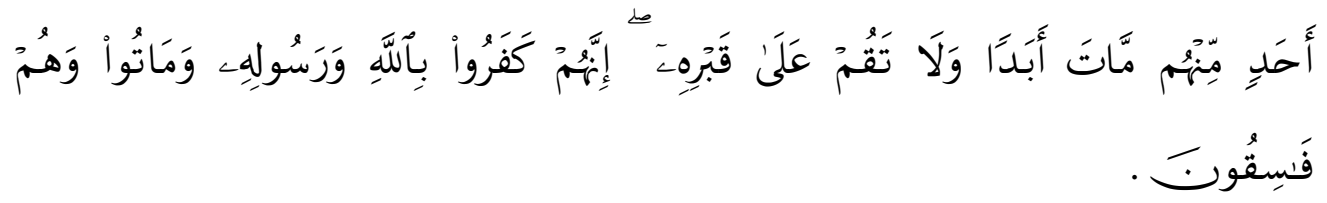

Terjemahannya: "Maka jika Allah mengembalikanmu kepada suatu golongan dari mereka, Kemudian mereka minta izin kepadamu untuk keluar (pergi berperang), Maka Katakanlah: "Kamu tidak boleh keluar bersamaku selama-lamanya dan tidak boleh memerangi musuh bersamaku. Sesungguhnya kamu Telah rela tidak pergi berperang kali yang pertama. Karena itu duduklah bersama orang-orang yang tidak ikut berperang. Dan janganlah kamu sekali-kali menyembahyangkan (jenazah) seorang yang mati di antara mereka, dan janganlah kamu berdiri (mendoakan) di kuburnya. Sesungguhnya mereka Telah kafir kepada Allah dan rasulNya dan mereka mati dalam keadaan fasik."

Dari keempat definisi di atas, bisa pahami bahwa terma Khawarij tidak tetap atau berubah-ubah mengikuti waktu dan dari siapa makna itu muncul. Misalnya, definisi ke-1 dirujukkan pada mereka yang keluar dari golongan Ali paska terjadinya arbitrase dengan Mu'awiyah; definisi ke-2 ditujukan pada mereka yang beriman atau untuk membedakan yang 'iman' dan yang 'kafir'; definisi ke-3 ditujukan pada mereka yang memberontak kepada pemerintah Ali. Singkatnya Khawarij di sini dimaknai sebagai pemberontak. Bahkan, pada masa Khalifah Abd al-Malik, siapapun yang memberontak kepada pemerintah, entah itu dari sekte Khawarij atau bukan, dianggap sebagai Khawarij; dan definisi ke-4 ditujukan kepada kaum munafik yang tidak mengikuti perang ketika perang Tabuk, meskipun, dikemudian hari, makna definisi ini (Jihad) dan juga definisi ke-2 direduksi oleh sekte Khawarij untuk melegitimasi dan dijadikan karakter dari dirinya. Jadi, makna yang mengarah ke sekte Khawarij, dengan melihat data-data sejarah dan karakter, adalah definisi ke-1 dan 3, dan definisi ke 2 dan 4 setelah direduksi. ${ }^{2}$ Untuk lebih jelasnya, mari kita telaah historis-nya kembali.

${ }^{2}$ Untuk lebih jelasnya, lih. W. Montgomery Watt, Study Islam Klasik: Wacana Kritik Sejarah, terj. Sukoyo dkk., (Yogyakarta: Tiara Wacana, 1999), 16-20. 


\section{Sejarah Kemunculan Sekte Khawarij}

Sejak awal penulis sadar bahwa, terkait sejarah kemunculan sekte Khawarij, teman-teman [diskusi di kelas] sudah mengetahuinya dengan baik dan bahkan mungkin sudah bosan mendegarnya karena sudah sering diulas dan diketengahkan. Namun, karena alasan akademis dan juga supaya kajian ini runtut, penulis mau tidak mau harus mengetengahkannya kembali.

Menurut data sejarah, di masa-masa awal Islam, umat muslim tidak mengalami perpecahan dan perbedaan pendapat tentang ajaran Islam dalam segala aspek, termasuk permasalahan keimanan. Jika terjadi ketidaktahuan atau ketidakfahaman, hal itu bisa ditanyakan langsung kejelasannya kepada Nabi Muhammad Saw. Situasi ini masih tetap bertahan hingga masa kekhalifahan Khulafau al-Rasyidin tiga awal, yakni Khalifah Abu Bakar asShiddiq ra., Umar Bin Khattab ra., dan paruh pertama masa pemerintahan Khalifah Usman bin Affan ra. Pada masa 'bersih' tersebut, meskipun di sana sini terdapat peristiwa pembangkangan dan penusukan terhadap Khalifah Umar bin Khattab, namun perpecahan belum terlalu nampak. Seandainya pun ada perpecahan, namun bukan pada masalah ushul sebagaimana permasalahan aqidah. Pada masa ini, sumber rujukan ajaran tertuju kepada para sahabat senior yang tidak diragukan lagi kemampuannya.

Menurut Ibnu Khaldun, dalam muqaddimah-nya, terkait keimanan para ulama salaf ketika itu (sahabat, tabi'in, tabi'it-tabi'in) -baik ketika Nabi masih hidup maupun pasca kewafatannya- menggantungkan ajarannya [tauhid, yang menjadi objek utama kalam] pada apa yang diajarkan oleh Nabi Muhammad, yakni sabda beliau ketika ditanya tentang iman: "Hendaklah engkau beriman kepada Allah, para malaikat-Nya, kitab-kitab-Nya, rasulrasul-Nya, dan hari akhir, dan engkau beriman kepada qadar, baiknya dan buruknya". Mereka mengikuti dan mengimani apa adanya dari ajaran tersebut, dan jika bertemu dengan ayat-ayat mutasyabihat, mereka menahan diri dari tindakan ta'wil dan menyerahkan maknanya kepada Allah Swt. Meskipun demikian bukan berarti pada masa salaf ini tidak muncul kelompok yang berbeda, menurut Ibnu Khaldun kala itu sudah muncul kelompok mujassimah/ tasybih/ anthromorpisme. ${ }^{3}$

Perpecahan umat Islam mulai nampak pada paruh kedua masa pemerintahan Utsman bin 'Affan dan bertambah kuat pada masa Khalifah Ali

\footnotetext{
${ }^{3}$ Ibnu Khaldun, Muqaddimah, terj. Ahmadie Thaha, (Jakarta: Pustaka Firdaus, cet II, 2000), 597-601.
} 
bin Abi Thalib, tepatnya pasca Ali menerima arbitrase yang ditawarkan Mu'awiyah. Umat Islam mulai ada benih-benih perpecahan pada paruh kedua masa Pemerintahan Utsman karena Utsman dianggap lemah dihadapan keluarganya yang mayoritas para elit dagang Quraisy yang kaya raya. Bukti tindakan itu adalah memecat gubernur-gubernur yang diangkat oleh Khalifat Umar dan menggantinya dengan mereka yang mempunyai darah keluarga dengannya. Melihat sikap Utsman seperti itu banyak sahabat yang pada awalnya mendukungnya berbalik memusuhinya, dan karena ini pula banyak muncul pemberontakan yang kemudian menyebabkan kematian Utsman. Meskipun, menurut Watt kesemua tuduhan tersebut tidak terbukti. Dalam artian, tuduhan-tuduhan itu tidak didukung dengan bukti-bukti yang kuat secara akademis. Menurutnya, peristiwa targis yang menimpa Ustman itu lebih pada dikarena persoalan politik dan ketidakmampuan orang-orang Arab (pengembara dan berbentuk pemerintahan kesukuan) dalam kehidupan yang diperintah dengan model pemerintahan kekhalifahan yang berisfat semination. ${ }^{4}$

Kemudian, terkait dengan arbitrase, diceritakan bahwa ketika dalam Perang Siffin, perang antara Ali dan Mu'awiyah, pihak Mu'awiyah terdesak, dan karena itu lalu Mu'awiyah mengangkat al-Qur'an di atas tombak sebagai tanda damai dan meminta untuk diadakan musyawarah (arbitrase). Melihat itu, dan karena desakan ahli Huffadz, Khalifah Ali menerimanya, meskipun dia sendiri merasa keberatan. Kemudian, diantara keduabelah pihak mengirim perwakilannya, Amr bin Ash sebagai wakil dari pihak Muawiyah dan Abu Musa al-Asy'ari dari pihak Ali. Singkat kata, dalam arbitrase ini, karena kelihaian Amr bin Ash dan kezuhudan Abu Musa al-Asy'ari, pihak Muawiyah menuai kemenangan, dan ketika itu pula dia menyatakan bahwa dirinya menjadi khalifah, meskipun Ali tidak mau menyerahkan jabatannya. ${ }^{5}$

Kekalahan Ali dalam arbitrase diatas, menimbulkan beberapa sikap pandangan yang nantinya menjadi sekte awal dalam kalam Islam, diantaranya ialah sekte Khawarij. Kelompok yang memisahkan dari kelompok Ali dan kemudian berbalik menyerangnya karena mereka menganggap Ali telah melakukan dosa besar dengan menghukumi sesuatu bukan dengan hukum Tuhan, yakni terkait arbitrase. Selain Khawarij, pada persoalan ini juga muncul dua sekte lain, yakni mereka yang tetap setia kepada Ali bahkan

\footnotetext{
${ }^{4}$ Watt, $10-11$

5 Harun Nasution, Teologi Islam: Aliran-aliran, Sejarah Analisa Perbandingan, (Jakarta: UI-Press, 2008), 7-9.
} 
fanatik membelanya (Syi'ah) dan mereka yang melepaskan diri dari penghakiman "salah" baik kepada Ali, Abu Musa al-Asy'ari, Muawiyah, Amr bin 'Ash (perang Siffin), Aisyah, Talhah, Zubair (perang Jamal), maupun Utsman bin 'Affan, dan menangguhkannya kepada Allah di akhirat kelak (Murji'ah). ${ }^{6}$

Pemisahan kaum Khawarij atas kelompok Ali terjadi dipertengahan perjalanan sekembalinya mereka dari arbitrase menuju ke Kuffah. Dari pertengahan perjalanan itu, kaum Khawarij memisahkan diri dan tidak kembali ke Kuffah, namun memilih untuk menuju dan berkumpul-menetap di Harura. ${ }^{7}$ Mereka berjumlah sekitar dua belas ribu orang dengan tokoh utamanya Abdullah ibnul Kiwa', Abdullah bin Wahab al-Rasibi al-Harami, dan Harqush bin Zuhair. Dua tokoh terakhir ini sering disebut dengan nama Dzi Tsadiyah (orang yang mempunyai payudara). ${ }^{8}$

Mengetahui peristiwa itu, Khalifah Ali memerintahkan beberapa sahabat untuk menginsafkan mereka, namun upaya itu hanya menghasilkan hasil yang minim, lebih banyak yang menolak daripada yang kembali. Salah satu sahabat yang berhasil menginsafkan beberapa dari kaum Khawarij adalah Abdullah bin Abbas. Karena masih banyak yang tidak mau kembali dan bahkan berbalik memberontak pemerintah, Khalifah Ali menyerangnya hingga Nahrawan menjadi medan pertempuran yang hebat. ${ }^{9}$ Pelumatan atas dan pemberontakan Khawarij terus berlangsung hingga tampuk pemerintahan pindah ke Dinasti Umayah, tepatnya pada masa Khalifah Abdul Malik bin Marwan. Pada masa khalifah ini 'negara' yang didirikan oleh sekte Khawarij telah dimusnahkan hingga habis. Tokoh yang pertama dibaiat oleh kaum Khawarij menjadi pemimpin negara mereka adalah Abdullah bin Wahab alRasibi, dan kemudian seperti Ibnu Azraq, Quthri Ibnul Fuja'ah, Athiyah dan seterusnya hingga negara itu hancur. ${ }^{10}$

${ }^{6}$ Fazlur Rahman, Revival and Reform in Islam: a Study of Islamic Fundamentalism, (England: Oneworld Publication, 2000), 39.

${ }^{7}$ Munawir Sjadzali, Islam dan Tata Negara: Ajaran, Sejarah, dan Pemikiran, ed. keV, (Jakarta: UI-Press, 1993), 217.

${ }^{8}$ Abi Manshur 'Abdul Qahir al-Tamimi al-Baghdadi, Kitab al-Milal wa al-Nihal, (Beirut: Dar al-Masyriq, tt), 60

9 Jabir Qumaihah, Beroposisi Menurut Islam, terj. Masykur Hakim, (Jakarta: Gema Insani Press, 1990), 106

${ }^{10}$ Muhammad Dhiauddin Rais, Teori Politik Islam, terj. Abdul Hayyi, dkk., (Jakarta: Gema Insani Press, 2001), 160 \& 175 
Bersama dengan berjalannya waktu, karena perbedaan pendapat di intern, sekte Khawarij berpecah menjadi beberapa sekte kecil lagi, diantaranya ialah: sekte al-Muhakkimah al-Ula, al-Zariqah, al-Najdiyah, alSufriyah, al-Maimunah, al-Syabibiyah (al-Sya'ibiyah), al-Hamziyah, alHazimiyah, al-Ma'lumiyah, al-Majhuliyah, al-Shalniyah, al-Akhnasiyah, alIbadiyah, al-Syibaniyah ma'a al-Syibliyah, al-Rasyidiyah, al-Hafshiyah, alYazidiyah, al-Haritsiyah, dan beberapa pecahan kecil dari pecahan Khawarij yang besar lainnya. ${ }^{11}$

\section{Pokok-pokok Pemikiran Politik Khawarij}

Perlukah umat Muslim menganggakat imam? Siapa yang berhak menjadi imam dan apa syarat-syaratnya? Bagaimana metode pengangkatannya? Dan, bagaimana menganggap sekte diluar dirinya? Pertanyaan-pertanyaan inilah yang menjadi fokus kajian politik sekte Khawarij.

Terkait pertanyaan pertama, Khawarij berpendapat bahwa umat muslim wajib mengangkat seorang imam, kecuali jika semua umat muslim sudah adil, bekerja sama dan saling menolong dalam kebaikan. Dalam arti jika umat muslim sudah bisa adil semua, mereka bisa tidak mengangkat seorang imam atau mendirikan sebuah pemerintahan. Pendapat yang terakhir ini muncul pada abad ke-7 dan dinyatakan oleh Khawarij sekte Najdiyah. ${ }^{12}$

Siapa yang berhak menjadi imam, Khawarij pertama-tama menyatakan bahwa setiap laki-laki muslim yang telah memenuhi 'syarat', berkebangsaan Arab, dan merdeka. Mereka juga berpendapat bahwa keimaman tidak boleh dimonopoli oleh suatu suku atau keluarga tertentu. Kemudian, setelah banyak umat muslim non-Arab dan budak masuk ke dalam Khawarij, pendapat tersebut berubah, yakni setiap laki-laki muslim yang telah memenuhi 'syarat' dengan tanpa memandang sebagai orang Arab maupun budak. ${ }^{13}$

Kemudian syarat-syarat, selain hal di atas, yang harus dipenuhi oleh kandidat imam ialah mampu berbuat adil, berilmu, pemberani, saleh, dan mengikuti apa yang tertera secara harfiah dalam al-Qur'an dan al-Sunnah. Jika sang kandidat tidak memenuhi syarat-syarat tersebut, maka kesempatannya untuk menjadi imam hilang. Hal ini pun juga berlaku bagi

\footnotetext{
${ }^{11}$ Abdul Qahir, al-Milal wa al-Nihal ...,57

12 Antony Black, Pemikiran Politik Islam: Dari Masa Nabi hingga Masa Kini, terj. Abdullah Ali dan Mariana A., (Jakarta: Serambi Ilmu Semesta, 2006), 49

${ }^{13}$ Sjadzali, Islam ..., 217-218
} 
imam yang telah dibai'at jika di tengah-tengah pemerintahannya ia melanggar salah-satu syarat tersebut. Bahkan, Khawarij menyatakan untuk memerangi dan membunuhnya. Hal ini karena ia dianggap telah melakukan dosa besar. Dan jika berdosa besar maka ia adalah kafir dan berhak untuk dibunuh. Namun, jika imam itu telah mempunyai atau melakukan syaratsyarat tersebut, semua umat muslim harus mematuhinya dan haram menurunkannya. $^{14}$

Terkait metode pengangakatan imam, pendapat Khawarij sama dengan mayoritas sekte dalam Islam, yakni dengan metode bai'at. Maksudnya, jalan untuk menuju keimamahan atau kekhalifahan yang konstitusional atau bahwa sumber kekuasaan khalifah hanya dapat dicapai melalui prosedur pemilihan umum umat, yang dicerminkan dengan prosedur pembaiatan. ${ }^{15}$

Dan jawaban atas pertanyaan yang terakhir, Khawarij berpendapat bahwa semua orang muslim diluar kelompoknya adalah kafir, maka halal untuk dibunuh. Dengan dasar ini, maka Khawarij membagi wilayah negara menjadi dua, yakni dar al-Salam dan dar al-Kuffar. Dar al-Salam adalah kelompok mereka sementara Dar al-Kuffar yang halal dijarah maupun dibunuh adalah semua orang muslim di luar kelompoknya, tidak termasuk di dalamnya kaum musyrik dzimmi. Oleh karena itu, kelompok yang terakhir ini tidak halal darahnya. Untuk membunuh orang-orang Dar al-Kuffar ini dinilai 'Jihad' dan harta mereka dinilai 'ghanimah' bagi Khawarij.

\section{Khawarij dan Neo-Khawarij: Persinggungan Konsep Politik?}

Sebagaimana disinggung di pendahuluan paper ini bahwa dewasa ini muncul sebuah istilah yang sering dilabelkan kepada sebuah kelompok yang mempunyai karakter tertentu dengan label 'neo-khawarij'. Menurut beberapa keterangan, label tersebut disandarkan kepada mereka karena mempunyai karakteristik yang sama dengan sekte 'khawarij', sebuah sekte yang mempunyai karakter suka mengkafirkan dan menggunakan kekerasan dalam menyelesaikan masalah. Pertanyaan yang muncul ialah apakah kedua kelompok tersebut (khawarij dan neo-khawarij) mempunyai kesamaan juga dalam hal konsep politik? Namun sebelum melacak hal ini, baik kiranya dituturkan terlebih dahulu siapa dan bagaimana karaktek kelompok yang

14 Ali Abdul Mu'ti Muhammad, Filsafat Politik antara Barat dan Islami, terj. Rosihon Anwar, (Bandung: Pustaka Setia, 2010), 286

${ }^{15}$ Rais, Teori Politik Islam ..., 129 
disebut sebagai neo-khawarij ini? Dan adakah kecocokan diantara karakter khawarij dan neo-khawarij tersebut?

Syeikh Hisyam al-Kabbani menuturkan neo-khawarij sebagai berikut;

The exercise of takfir is the chief mark by which the neokhawarij can be recognized in our time. They are those who address the muslims with the libelous chants of: $k u f r$ (unbelief), bid'a! (innovation), shirk! (idolatry), haram! (forbidden), without proof or justification other than their own vain lusts, and without solution other than exclusionism and violence against anyone with whom they disagree. ${ }^{16}$

Sementara Quintan Wiktorowicz dalam buku Radical Islam Rising: Muslim Extremism in the West menyatakan;

Groups that use takfir and condone violence, like al-Muhajiroun and al-Qaeda, are called 'neo-khawarij' to connote the deviancy of the 'khawarij' sect that stoked violence among muslims during the seventh century ${ }^{17}$

Dan Nurhaidi Hasan dalam bukunya Laskar Jihad: Islam, Militancy, and the Quest for Identity in Post-new Order menulis;

From the salafis' point of view, the use of the takfir doctrine is characteristic of what are called 'neo-kharijite groups' (neokhariji), inspired by the thinking of qutb. Thalib conciders this doctrine to be a modern manifestation of the politic of the kharijites, who were notorious for declaring all other muslims to be unbelievers; their confidence in making such broad judgments was founded on the tawhid hakimiyya or mulkiyya. ${ }^{18}$

Dari kedua keterangan tersebut bisa dipahami bahwa kelompok yang dikategorikan sebagai neo-khawarij adalah mereka yang [suka] melakukan pengkafiran, pembid'ahan, pensyirikan, pengharaman, dan kekerasan kepada

16 Muhammad Hisham Kabbani, The Approach Of Armageddon? An Islamic Perspective, (America: Islamic Supreme Council of America, 2003), 161.

17 Quintan Wiktorowicz, Radical Islam Rising: Muslim Extremism in the West, (America: Rowman \& Littlefield Publishers, inc, 2005), 186.

${ }^{18}$ Nur Haidi Hasan, Laskar Jihad: Islam, Militancy, and the Quest for Identity in Post-New Order, (Cornell Southeast Asia Program, 2006), 144. 
orang atau kelompok yang berbeda dengan pemahaman mereka. Dan juga, karena konsekuensi logis dari beberapa karakter tersebut, mereka juga sering menyebut istilah jihad dan taubat.

Kelompok yang bisa dikategorikan kepada neo-khawarij diantaranya adalah al-Muhajiraoun, al-Qaeda (Quintan Wiktorowicz), Wahabi, Salafi (Hisyam al-Kabbani) $^{19}$, Jama'ah Islamiyah, Hizbut Tahrir, DII/TII pimpinan Kartosuwiryo, LDII dan kelompok-kelompok lain yang mempunyai karakter sebagaimana disebutkan di atas.

Jika dilihat dari karakter-karakter ini maka neo-khawarij memang mempunyai kesamaan karakter dengan 'khawarij', terutama sekali yaitu tentang sikap suka mengkafirkan kelompok yang berbeda dengan mereka, suka kekerasan, dan literalis atau menafsirkan nash secara lahiriyah.

Kemudian, terkait konsep politik kaum neo-khawarij, karena sangat banyak kelompok-kelompok yang bisa dimasukan ke dalam kategori neokhawarij, untuk mempermudah bahasan penulis akan memfokuskan pada konsep politik Hizbut Tahrir. Sebab kelompok ini, dibanding dengan kelompok-kelompok -kontemporer- lainnya, nampak lebih getol dalam bergerak di wilayah politik.

Bagi HT, semua hal yang ada di dunia ini sudah diatur semua oleh alQur'an dan al-Hadis, maka dengan demikian semua hal selain dari al-Qur'an dan al-Hadis adalah salah atau haram diiukti atau bahkan disebut 'istilahnya' oleh umat muslim, termasuk di dalamnya adalah sistem demokrasi. Demokrasi bagi mereka adalah sistem kufur. Bagi HT, Islam menyatakan bahwa kekuasaan memang berada di tangan rakyat sebagaimana yang dalam demokrasi, namun tidak untuk kedaulatan, sebab yang disebut terakhir ini bagi HT berada pada syara'. Dengan demikian maka tiada hukum selain dari syara' yang tidak lain adalah Allah Swt. Ini sama persis dengan statemen awal Khawarij, yakni la hukma illa lillah.

HT [Indonesia] juga menyatakan sebagai berikut;

Undang-undang yang berlaku di Negara ini [indonesia, pen] memang UUD 1945, namun bukan berarti HT tunduk dan patuh pada UUD. Aktivitas dakwah yang HT lakukan tidak ada sama sekali yang mengindikasikan tunduk dan patuh kepada UU yang berlaku, kecuali kepada hal-hal administrasi saja, yang itu tidak terkait dengan hokum syara', seperti syarat ijin

\footnotetext{
${ }^{19}$ Kabbani, The Approach of Armageddon..., 161
} 
menyelenggarakan aksi yang memakai fasilitas-fasilitas umum. Dalam UUD 1945 ada hal yang bertentangan dengan hokum syara' namun juga ada yang tidak, dalam hal ini seperti perijinan yang itu tidak ada kaitannya dengan hukum syara'. Tidak ada satupun perundang-undangan dari system kufur yang dijalankan oleh Hizbut Tahrir hingga detik ini, kami tetap berpegang teguh kepada ahkam asyar'iyyah sebagai landasan dalam berbuat. ${ }^{20}$

Statemen ini selain meneguhkan la hukma illa lillah di atas juga menunjukkan bahwa HTI menolak UUD negara Indonesia yang dengan demikian bisa dikatakan memberontak kekuasaan yang sah yang merupakan ciri khas Khawarij. Yang terakhir ini sebagaimana dinyatakan oleh Syeikh Hisyam al-Kabbani;

Praktik mengafirkan (takfîr) sesama muslim dan mengangkat senjata untuk menghadapi pusat otoritas Islam, yaitu kekhalifahan, merupakan dan akan terus menjadi ciri khas kelompok Khawarij pada masa lalu dan kini. ${ }^{21}$

Selain beberapa poin di atas, sebenarnya masih banyak lagi poin-poin lain yang sesuai antara HT -dan kelompok-kelompok neo-khawarij laindengan Khawarij baik dalam segi konsep politik, ideologi, praktek ataupun lainnya. Namun, karena keterbatasan waktu dan halaman, penulis kira sampai di sini sudah cukup untuk menunjukkan bahwa gerakan-gerakan atau kelompok-kelompok islamis-radikalis (neo-khawarij) dewasa ini mempunyai kesamaan dengan sekte awal islam, yakni Khawarij.

\section{Penutup}

Dari uraian di atas maka bisa dipahami bahwa:

1. Dalam diri Islam, secara historis, memang ada sekte yang menjadi rujukan kaum fundamentalis-radikalis tersebut, yakni Khawarij. Khawarij adalah salah satu dari tiga sekte awal Islam. Sekte ini mayoritas terdiri dari huffadz dan mempunyai karakter literalis, suka

${ }^{20}$ Adi Victoria, "Bantahan Tulisan 'Paradoks Pemikiran Politik Hizbut Tahrir' yang ditulis oleh Shinichi Kudo", (http://adivictoria1924.wordpress.com atau www.hizbuttahrir.or.id, diakses tanggal 23 Januari 2011)

${ }^{21}$ Kabbani, The Approach of Armageddon..., 160. 
mengkafirkan, dan kekerasan, bahkan tidak segan-segan menghalalkan darah kepada kelompok [muslim] di luar fahamnya.

2. Pemikiran politik Khawarij, karena dipengaruhi oleh beberapa ajaran dan karakter di atas, adalah (1) semua umat muslim berhak menjadi imam tanpa melihat jenis kelamin, ras dan sukunya, (2) imam harus adil, saleh, pemberani, dan mengikuti makna literer nash, (3) Imam diba'iat oleh umat muslim dan setelah terpilih seorang khalifah umat muslim harus patuh kepadanya, selagi tidak melenceng dari syari'at [dengan penafsiran literer], (4) jika imam melenceng, ia harus tobat atau diturunkan paksa dan bahkan umat muslim dianjurkan untuk menyerang dan membunuhnya, (5) wilayah negara dibagi menjadi dua, dar al-harb dan dar al-salam, (6) umat muslim diluar pemahamannya dan tidak mengikuti hukum Allah ala mereka, mereka adalah kafir dan karenanya halal dibunuh dan hartanya merupakan harta rampasan perang. Pemikiran politik Khawarij ini jelas terpengaruh oleh ajaran pokok mereka, yakni tentang pelaku dosa besar, Jihad, dan pemahaman yang literalistik atas nash-nash agama.

3. Antara Khawarij dan Neo-Khawarij mempunyai kesamaan karakter dan konsep politik, meskipun para pakar menyatakan bahwa antara mereka tidak ada kesinambungan secara geneologi. Titik kesamaan yang sangat kentara atau menonjol dari mereka adalah suka mengkafirkan, getol mengumandangkan jihad, melakukan kekerasan dalam menyelesaikan masalah atau kepada kelompok di luar pemahamannya, literer dalam memahami nash, menentang pemerintahan yang sah (pemberontak), menolak semua hal yang tidak terdapat secara lahirinyah dalam nash, dan bahkan menghalalkan darah sesama muslim yang bukan golongannya, dan lain sebagainya. Kelompok yang disinyalir para pakar masuk dalam kategori neokhawarij antara lain Jamaah Islamiyah, al-Qaeda, Wahabi, Salafi, DII/TII, LDII, al-Muhajiroun, dan lain-lain. 


\section{DAFTAR PUSTAKA}

Al-Baghdadi, Abi Manshur 'Abdul Qahir al-Tamimi Kitab al-Milal wa alNihal, Beirut: Dar al-Masyriq, tt.

Adi Victoria, "Bantahan Tulisan 'Paradoks Pemikiran Politik Hizbut Tahrir' yang ditulis oleh Shinichi Kudo", (http://adivictoria1924.wordpress.com atau www.hizbut-tahrir.or.id, diakses tanggal 23 Januari 2011)

Black, Antony Pemikiran Politik Islam: Dari Masa Nabi hingga Masa Kini, terj. Abdullah Ali dan Mariana A., (Jakarta: Serambi Ilmu Semesta, 2006)

Hasan, Nur Haidi, Laskar Jihad: Islam, Militancy, and the Quest for Identity in Post-New Order, Cornell Southeast Asia Program, 2006.

Kabbani, Muhammad Hisham, The Approach Of Armageddon? An Islamic Perspective, America: Islamic Supreme Council of America, 2003.

Khaldun,I bnu Muqaddimah, terj. Ahmadie Thaha, Jakarta: Pustaka Firdaus, cet II, 2000.

Muhammad, Ali Abdul Mu'ti, Filsafat Politik antara Barat dan Islami, terj. Rosihon Anwar, Bandung: Pustaka Setia, 2010.

Nasution, Harun Teologi Islam: Aliran-aliran, Sejarah Analisa Perbandingan, Jakarta: UI-Press, 2008.

Qumaihah, Jabir Beroposisi Menurut Islam, terj. Masykur Hakim, (Jakarta: Gema Insani Press, 1990)

Rais, Muhammad Dhiauddin, Teori Politik Islam, terj. Abdul Hayyi, dkk., Jakarta: Gema Insani Press, 2001.

Rahman, Fazlur Revival and Reform in Islam: a Study of Islamic Fundamentalism, England: Oneworld Publication, 2000.

Sjadzali, Munawir Islam dan Tata Negara: Ajaran, Sejarah, dan Pemikiran, ed. ke-V, Jakarta: UI-Press, 1993.

Watt, Motgomerry Studi Islam Klasik: Wacana Kritik Sejarah, terj. Sukoyo, dkk. Yogyakarta: Tiara Wacana, 1999. 
Wiktorowicz, Quintan, Radical Islam Rising: Muslim Extremism in the West, America: Rowman \& Littlefield Publishers, inc, 2005. 